\title{
Copper Solubility and Redox Equilibria in Magnesia Saturated $\mathrm{CaO}-\mathrm{CuO}_{\mathrm{x}}-\mathrm{FeO}_{\mathrm{x}}$ Slags
}

\author{
MICHAEL SOMERVILLE, SHOUYI SUN, and SHARIF JAHANSHAHI
}

\begin{abstract}
New measurements on solubility of copper and redox equilibria in magnesia-saturated calcium ferrite-based slags are presented. These data were obtained from equilibrium experiments at $1573 \mathrm{~K}\left(1300^{\circ} \mathrm{C}\right)$ and over a range of oxygen partial pressures of $10^{-11}$ to $10^{-5} \mathrm{~atm}$, through equilibrating the slag with metallic copper in magnesia crucibles under a flowing $\mathrm{Ar}-\mathrm{CO}-\mathrm{CO}_{2}$ gas mixture. At low oxygen partial pressures, copper was found to dissolve into slag as a univalent species $\left(\mathrm{CuO}_{0.5}\right)$ with a linear dependence on the oxygen partial pressure (in logarithm), with a slope of 0.23 . At higher oxygen partial pressures $\left(>10^{-7} \mathrm{~atm}\right)$, the data suggest a divalent copper species becomes significant $(\mathrm{CuO})$ and causes the dependence on oxygen partial pressure to increase. The determination of the $\mathrm{Fe}^{3+} / \mathrm{Fe}^{2+}$ ratio in the slag was effected by the cuprous $\left(\mathrm{Cu}^{+}\right)$content, which acts to increase the apparent ferrous $\left(\mathrm{Fe}^{2+}\right)$ content during acid digestion. A correction procedure was applied to the $\mathrm{Fe}^{3+} / \mathrm{Fe}^{2+}$ ratio based on the calculated $\mathrm{Cu}^{+}$content of the slag. The procedure assumes that the activity coefficients of $\mathrm{CuO}_{0.5}$ and $\mathrm{CuO}$ $\left(\gamma_{\mathrm{CuO}_{0.5}}\right.$ and $\left.\gamma_{\mathrm{CuO}}\right)$ in these slags are independent of oxygen partial pressure. The calculated activity coefficients of $\mathrm{CuO}_{0.5}$ and $\mathrm{CuO}$ were 3.43 and 0.29 , respectively. The corrected $\mathrm{Fe}^{3+} /$ $\mathrm{Fe}^{2+}$ ratio had a linear dependence of 0.17 on the oxygen partial pressure over the entire oxygen partial pressure range. This agrees with similar data from the literature.
\end{abstract}

DOI: $10.1007 / \mathrm{s} 11663-014-0157-1$

(C) The Author(s) 2014. This article is published with open access at Springerlink.com

\section{INTRODUCTION}

THERE is growing acceptance in the use of calcium ferrite-based slags in the processing of copper concentrates and in the continuous production of copper metal. Commercial processes such as the Mitsubishi process, ${ }^{[1-4]}$ the Kennecott flash converting process,${ }^{[5-7]}$ as well as other proposed continuous and single-stage converting processes $^{[8-10]}$ advocate the use of calcium ferrite slags. The advantages of calcium ferrite slags over the more conventional iron silicate slags include

- A lower dissolved copper content at a given activity of copper in slag, ${ }^{[11,12]}$

- A higher capacity to dissolve ferric iron and, hence, magnetite, and ${ }^{[13]}$

- A higher capacity for some acidic minor elements such as arsenic and antimony. ${ }^{[14,15]}$

Most of the thermodynamic investigations into calcium ferrite slags have concentrated on liquidus boundaries at copper-making temperatures, ${ }^{[10,16-20]}$ iron redox equilibria, ${ }^{10-18,21-24]}$ and the solubility of copper in slag. ${ }^{[1,15,19,25,26]}$ Nikolic et al. ${ }^{[27]}$ and Hidayat et al. ${ }^{[28]}$ investigated the thermodynamics of complex slag systems relevant to modern copper smelting and converting

MICHAEL SOMERVILLE, Research Team Leader, and SHOUYI SUN and SHARIF JAHANSHAHI, Senior Principal Research Scientists, are with the CSIRO - Minerals Down Under National Research Flagship, Box 312 Clayton South, VIC 3168, Australia. Contact e-mail: Michael.somerville@csiro.au

Manuscript submitted July 7, 2014.

Article published online August 13, 2014. processes as part of a thermodynamic modeling study. Jak et al. ${ }^{[5]}$ also investigated calcium ferrite-based slag systems in a study on the control of slag freeze linings which are used in new copper converting processes.

In most studies, copper metal is assumed to dissolve into the slag as an univalent species $\left(\mathrm{CuO}_{0.5}\right)$. The dissolved copper has a linear dependence on the oxygen partial pressure in logarithm, especially at low oxygen partial pressures of about $0.22 .^{[11]}$ At higher oxygen partial pressures, the linear dependence has been observed to break down, and the copper content of slag has been shown to increase with a higher dependency. There is some uncertainty where the change in dependence on oxygen partial pressure occurs. In the work of Eerola et al., ${ }^{[14]}$ the change occurred at an oxygen partial pressure of about $10^{-7} \mathrm{~atm}$, while for Yazawa and Takeda ${ }^{[11]}$ and Takeda et al., ${ }^{[15]}$ the change occurred at about $10^{-5}$ atm. Eerola et al. ${ }^{[14]}$ attributed this increased dependence to a decrease in the activity coefficient of $\mathrm{CuO}_{0.5}\left(\gamma \mathrm{CuO}_{0.5}\right)$. The formation of a bivalent copper oxide species $(\mathrm{CuO})$, which would also account for the increase in dependency, was also considered by Eerola et al. ${ }^{[14]}$ and Takeda et al. ${ }^{[15]}$ However, no quantitative understanding was derived from those studies.

In this work, the dissolution of copper into calcium ferrite slags was investigated with particular reference to the copper species and the $\mathrm{Fe}^{3+} / \mathrm{Fe}^{2+}$ ratio of the slag at high oxygen partial pressures. The bivalent copper oxide species $(\mathrm{CuO})$ was assumed to exist in conjunction with the univalent species $\left(\mathrm{CuO}_{0.5}\right)$, and its concentration in the slag was estimated by a specifically designed procedure involving the use of activity coefficients of 
$\mathrm{CuO}$ and $\mathrm{CuO}_{0.5}\left(\gamma_{\mathrm{CuO}}\right.$ and $\left.\gamma_{\mathrm{CuO}_{0.5}}\right)$. Fitting to the experimental solubility data over the range of oxygen partial pressures used $\left(10^{-11}\right.$ to $\left.10^{-5} \mathrm{~atm}\right)$ allowed these activity coefficients to be calculated. This information, combined with their activities, enabled the amount of the two species $\left(\mathrm{CuO}\right.$ and $\left.\mathrm{CuO}_{0.5}\right)$ in the slag to be calculated. The measured apparent $\mathrm{Fe}^{3+} / \mathrm{Fe}^{2+}$ ratio in the slag was then adjusted based on the calculated $\mathrm{CuO}_{0.5}$ content. The experimental work was performed using magnesia crucibles at $1573 \mathrm{~K}\left(1300{ }^{\circ} \mathrm{C}\right)$.

\section{EXPERIMENTAL}

\section{A. Materials}

Materials used in the equilibrium testwork were prereduced calcium ferrite slag, copper metal, and $\mathrm{CO}-\mathrm{CO}_{2}-\mathrm{Ar}$ gas mixtures. An initial calcium ferrite master slag, containing 23 pet $\mathrm{CaO}$, was prepared in air from AR grade calcium carbonate and ferric oxide. Batches of master slag were pre-reduced under controlled oxygen partial pressures in a sealed vertical tube furnace at $1573 \mathrm{~K}\left(1300{ }^{\circ} \mathrm{C}\right)$. The use of the pre-reduced slag shortened the time required for the system to reach equilibrium and also prevented the precipitation of fine copper prills as the slag became reduced.

The oxygen partial pressures in the gas mixtures were fixed by controlling the proportion of $\mathrm{CO}, \mathrm{CO}_{2}$, and $\mathrm{Ar}$ in the gas phase. The gases were supplied by BOC Ltd. Food grade $\mathrm{CO}_{2}$, welding grade $\mathrm{Ar}$, and chemically pure $\mathrm{CO}$ were used.

The molten slag and copper phases were contained in small magnesia crucibles. The gases were dried and deoxygenated prior to use by passing through silica gel and copper turnings at $773 \mathrm{~K}\left(500^{\circ} \mathrm{C}\right)$, respectively, before entering the furnace.

\section{B. Procedure}

Both the pre-reduction and the equilibrium tests were performed in a vertical tube furnace. The experiments were conducted using a recrystallized alumina work tube which was heated externally by molybdenum disilicide elements. Brass end caps sealed the work tube and allowed the passage and removal of gas mixtures. The magnesia crucible was attached to an alumina lance which in turn was attached through an 'O' ring seal to the top end cap. During experiments, the crucible rested on a cast ceramic platform which was supported by the bottom end cap. The temperature at the base of the crucible was measured by a thermocouple embedded in the platform. The ceramic platform was situated at the bottom edge of the constant temperature hot zone $\left( \pm 2{ }^{\circ} \mathrm{C}\right)$ close to the center of the work tube. A schematic diagram of the apparatus is shown in Figure 1.

The flow of gases was individually controlled by precalibrated electronic mass-flow controllers. The gases were then mixed and passed into the furnace tube via the bottom end cap, over the melt and then exhausted

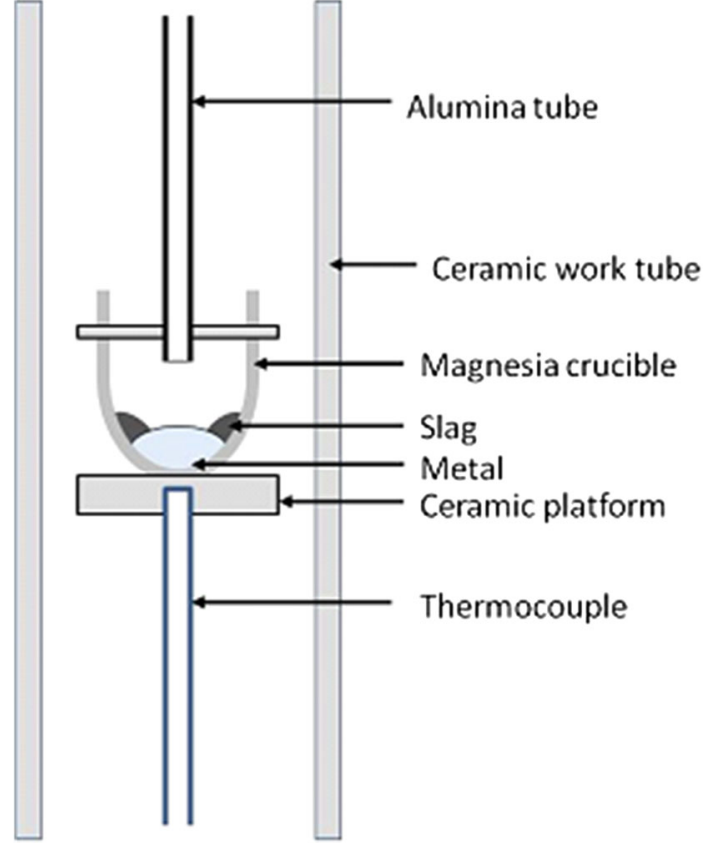

Fig. 1-Schematic diagram of the experimental apparatus.

through the lance which held the crucible. The following procedure was used:

The tube furnace was preheated to $1073 \mathrm{~K}\left(800{ }^{\circ} \mathrm{C}\right)$. The crucible assembly was placed in the cold zone at the top of the furnace. The cool end of the lance holding the crucible was connected to a bubbler seal. A small flow of $\operatorname{Ar}$ (about $200 \mathrm{ml} / \mathrm{min}$ ) was passed into the lower section of the furnace and was removed via the top alumina lance and bubble seal. In this way, the furnace tube was flushed of oxygen for about 30 minutes. The crucible was then lowered to the hot zone of the furnace and rested on a cast ceramic stand. The temperature of the furnace was increased so the crucible would reach $1573 \mathrm{~K}\left(1300^{\circ} \mathrm{C}\right)$.

When the crucible was at $1573 \mathrm{~K}\left(1300{ }^{\circ} \mathrm{C}\right)$, a predetermined gas mixture $\left(\mathrm{CO}-\mathrm{CO}_{2}\right)$ was introduced through the bottom end cap and removed with the Ar. The gas mixture was heated as it flowed up the furnace tube and into the crucible. The gas mixture and melt were allowed to react for a set period of time. At the end of the equilibration period, the crucible was quickly removed from the furnace and quenched in water.

Metallic copper and slag were removed from the crucible. The slag was pulverized in a mortar and pestle, and analyzed for metal oxides using an inductively coupled plasma technique. The ferrous iron content of the slag samples was determined using standard wet chemical procedures.

\section{RESULTS}

Preliminary experiments showed that the reacting phases (gas, slag, and copper) reached constant composition within 24 hours of reaction. Twenty-four hours was allowed for all subsequent experiments. 
Table I. Analytical Results (Weight Percentage)

\begin{tabular}{|c|c|c|c|c|c|c|c|c|}
\hline No. & $\mathrm{pO}_{2}(\mathrm{~atm})$ & $\mathrm{Cu}$ & $\mathrm{CaO}$ & $\mathrm{Fe}^{\mathrm{tot}}$ & $\mathrm{Fe}^{2+}$ & $\mathrm{MgO}$ & $\mathrm{CO} \mathrm{ml} / \mathrm{min}$ & $\mathrm{CO}_{2} \mathrm{ml} / \mathrm{min}$ \\
\hline 1 & $10^{-11}$ & 0.48 & 23.5 & 52.7 & 37.8 & 4.2 & 656.0 & 144.0 \\
\hline 2 & $10^{-10}$ & 0.69 & 23.2 & 50.7 & 32.2 & 5.7 & 472.3 & 327.7 \\
\hline 3 & $10^{-9}$ & 1.18 & 22.7 & 51.8 & 29.2 & 4.5 & 250.4 & 549.6 \\
\hline 4 & $10^{-8}$ & 1.94 & 22.2 & 50.5 & 24.2 & 4.6 & 100.8 & 699.2 \\
\hline 5 & $10^{-7}$ & 3.31 & 21.3 & 49.0 & 20.4 & 5.6 & 34.9 & 765.1 \\
\hline 6 & $10^{-6}$ & 6.85 & 20.6 & 47.0 & 17.0 & 3.8 & 11.4 & 788.6 \\
\hline 7 & $10^{-5}$ & 19.92 & 17.0 & 41.0 & 21.1 & 3.3 & 3.6 & 796.4 \\
\hline
\end{tabular}

Seven gas-slag-metal equilibrium experiments were performed. The oxygen partial pressures and the composition of the copper-saturated slag phase are presented in Table I. The oxygen partial pressure was controlled through the $\mathrm{CO} / \mathrm{CO}_{2}$ ratio in the gas. The gas compositions used are also shown in Table I.

The magnesia content of the slag is variable, shows no relationship with oxygen partial pressure, and is much higher than other measured values, ${ }^{[3]}$ and higher than recent measurements made by Yan et al. ${ }^{[25]}$ The likely reason for the elevated levels is the incorporation of part of the magnesia-wustite solid solution $\left(\left[\mathrm{Mg}, \mathrm{Fe}_{\mathrm{O}} \mathrm{O}_{\mathrm{x}}\right)\right.$ surface layer into the slag sample. It is also possible that solid magnesia could be deposited in the slag due to slight temperature differences between the edge and center of the crucible coupled with convective movement of the molten slag. The slightly increased magnesia content in the slags is not expected to have a large influence on the thermodynamics of copper and iron.

Figure 2 shows the effect of oxygen partial pressure on the copper content of calcium ferrite slag. The straight line section of the plot has a slope of 0.23 which is slightly higher than the slope obtained by Yazawa and Takeda ${ }^{[11]}$ for equilibrium between copper metal-gas and calcium ferrite slag (0.22). The deviation from linearity at low oxygen partial pressure $\left(10^{-11} \mathrm{~atm}\right)$ is probably due to a small amount of entrained metallic copper which will have a pronounced effect on the total copper content at low dissolved copper levels. At these low oxygen partial pressures, the slag is also likely to be saturated with metallic iron which could also increase the apparent copper solubility in slag. The break in linearity at high oxygen partial pressures is assumed to be due to increasing amounts of bivalent copper $(\mathrm{CuO})$ in the slag. Alternatively, the activity coefficient of $\mathrm{CuO}_{0.5}\left(\gamma \mathrm{CuO}_{0.5}\right)$ may decrease with increasing $\mathrm{pO}_{2}$. With a constant activity of $\mathrm{CuO}_{0.5}\left(a_{\mathrm{CuO} 0.5}\right)$, the concentration of copper would then increase.

Figure 3 shows the effect of increasing oxygen partial pressure on the $\mathrm{Fe}^{3+} / \mathrm{Fe}^{2+}$ ratio of slag. A close to linear dependence has been obtained for oxygen partial between $10^{-10}$ and $10^{-7}$ atm. The observed decline in the $\mathrm{Fe}^{3+} /$ $\mathrm{Fe}^{2+}$ ratio at high oxygen partial pressures is due to the effect that copper has on ferrous iron during acid digestion of the slag prior to chemical analysis. Cuprous copper reacts with and reduces ferric iron according to Eq. [1]:

$$
\mathrm{Cu}^{+}+\mathrm{Fe}^{3+}=\mathrm{Fe}^{2+}+\mathrm{Cu}^{2+} \text {. }
$$

This reaction is thermodynamically favored to occur until essentially all the univalent copper is consumed. As

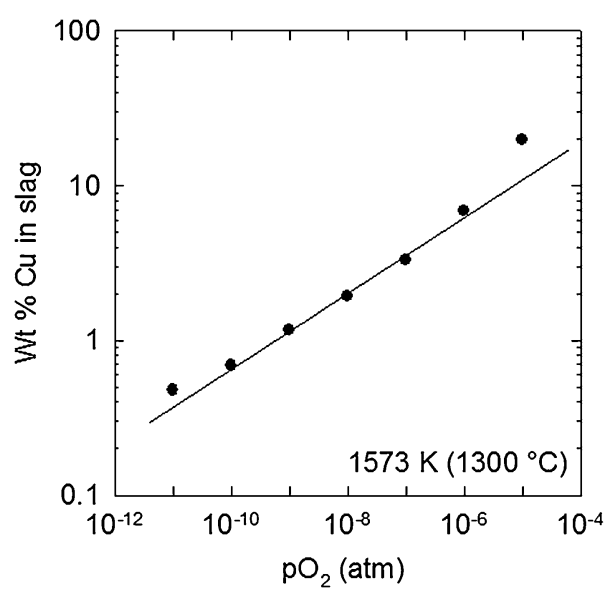

Fig. 2-The effect of oxygen partial pressures on the copper content of slag at $1573 \mathrm{~K}\left(1300{ }^{\circ} \mathrm{C}\right)$.

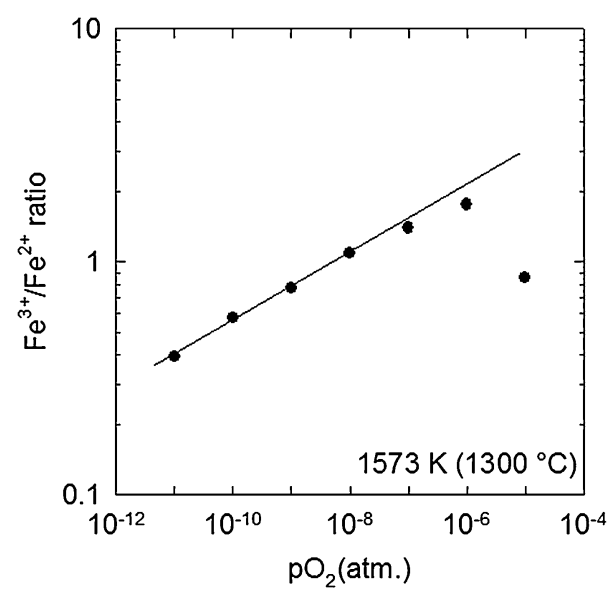

Fig. 3-The effect of oxygen partial pressure on the apparent $\mathrm{Fe}^{3+} /$ $\mathrm{Fe}^{2+}$ ratio in slag at $1573 \mathrm{~K}\left(1300{ }^{\circ} \mathrm{C}\right)$.

a result, an exaggerated high ferrous iron content of the slag is obtained, and the apparent $\mathrm{Fe}^{3+}$ and $\mathrm{Fe}^{2+}$ results need to be corrected for the $\mathrm{Cu}^{+}$copper present in the original slag. The usual practice ${ }^{[29,30]}$ is to assume that all the copper in the slag is present as cuprous oxide and then base the correction on the total copper content in the slag. However, the plot in Figure 2 suggests that some of the copper in the slag may exist as cupric oxide $(\mathrm{CuO})$. If this is the case, then the correction is more difficult since there is no established method of measur- 
ing the $\mathrm{Cu}^{2+} / \mathrm{Cu}^{+}$ratio in slag which does not also simultaneously affect the $\mathrm{Fe}^{3+} / \mathrm{Fe}^{2+}$ ratio.

\section{DISCUSSION}

\section{A. Copper Content of Slag}

Figure 4 shows a plot of the ratio of wt pet $\mathrm{Cu}$ to the copper activity $\left(\mathrm{a}_{\mathrm{Cu}}\right)$ in slag against $\mathrm{pO}_{2}$ and compares similar data from Palacios and Gaskell ${ }^{[12]}$ and the correlation of Yazawa and Takeda. ${ }^{[1]}$ In Figure 4, the copper content of slag was divided by the activity of copper so the data from Palacios and Gaskell ${ }^{[12]}$ could be compared to that of the present work.

In general, the data of Palacios and Gaskell ${ }^{[12]}$ show a small consistent difference compared with the present work. This difference is small considering the range of copper contents at each oxygen partial pressure. In general, the dissolved copper content in slag is slightly lower than in the present work which is reflected in their slightly higher activity coefficient for $\mathrm{CuO}_{0.5}$. The correlated data of Yazawa and Takeda, ${ }^{[11]}$ represented by Eq. [2], show close agreement with the present work. Possible reasons for the higher dissolved copper in the results of the present work compared to the results of Palacios and Gaskell ${ }^{[12]}$ include different $\mathrm{CaO}$ and $\mathrm{MgO}$ contents of the slag, the presence of copper prills in the slag, or systematic differences in the oxygen partial pressure between the studies.

$$
\log (\text { pct } \mathrm{Cu})=0.221 \log \left(\mathrm{pO}_{2}\right)+2490 / \mathrm{T}+0.455 \text {. }
$$

The slag used by Palacios and Gaskell ${ }^{[12]}$ was saturated with lime (about 30 wt pct $\mathrm{CaO}$ ) compared to about 22 pct in this work. It is thus possible that increasing $\mathrm{CaO}$ in calcium ferrite slag may have resulted in a decrease in the dissolved copper content of the slag. However, Yazawa and Takeda ${ }^{[1]}$ showed that the copper content in calcium ferrite slag is almost independent of lime content.

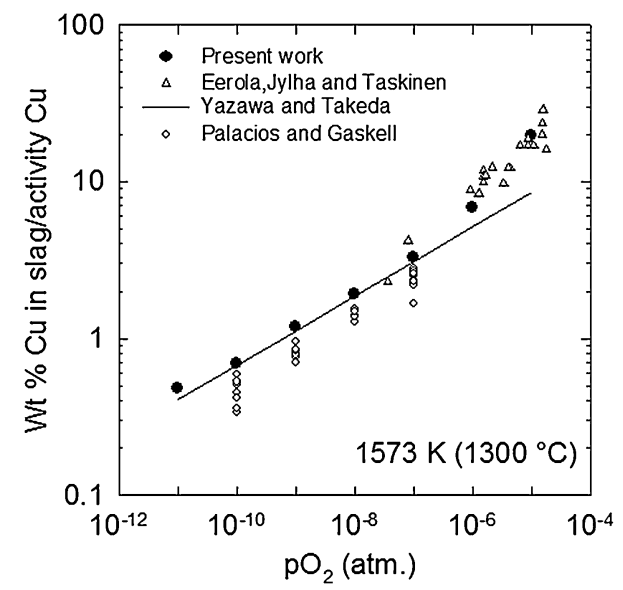

Fig. 4-Plot of $\mathrm{Cu}$ in slag at unit copper activity against $\log \mathrm{pO}_{2}$ comparing data calculated from Eerola et al. ${ }^{[14]}$ and from Palacios and Gaskell ${ }^{[12]}$ and the correlation of Yazawa and Takeda. ${ }^{[11]}$
It is not known how magnesia in calcium ferrite slag will affect the dissolved copper content. Elliott et al. ${ }^{[30]}$ showed that the addition of magnesia to iron silicate slags decreased the copper content. Hence, it is unlikely that the increased copper content of slag in the present work, compared to Palacios and Gaskell, ${ }^{[12]}$ was due to magnesia in the slag.

In the present work, precautions were made to minimize the precipitation of copper prills in the slag before the slag reached the equilibrium oxygen partial pressure. If copper prills did precipitate at high oxygen partial pressures, then the difference between the present work and the data of Palacios and Gaskell ${ }^{[12]}$ would expected to be greater at these oxygen partial pressures. Since the difference in the two data sets does not seem to be related to oxygen partial pressure, the precipitation of copper prills appears not to account for the observed difference.

Figure 4 shows a systematic difference between the present work and the data of Palacios and Gaskell. ${ }^{[12]}$ This difference could be due to the incorrect control of oxygen partial pressures in the experiments. It is unlikely to be due to inefficient gas cleaning as this problem usually results in very high oxygen content in the gas stream. It is possible that either in the present work the oxygen partial pressure was about half an order of magnitude too high, or the gas composition used by Palacios and Gaskell was too low.

Palacios and Gaskell ${ }^{[12]}$ showed that a plot of $a \mathrm{CuO}_{0.5}$ against the mole fraction of $\mathrm{CuO}_{0.5}\left(X_{\mathrm{CuO}_{0.5}}\right)$ was linear over the range of oxygen partial pressure used in their work $\left(10^{-7}\right.$ to $10^{-10}$ atm). The average $\gamma_{\mathrm{CuO}_{0.5}}$ was $4.17 \pm 0.60$, with pure liquid copper as the standard state. Takeda ${ }^{[31]}$ also performed equilibrium experiments among calcium ferrite slag, copper, and gas. In this work, Takeda showed that $\gamma_{\mathrm{CuO}_{0.5}}$ changed slowly with $\mathrm{pO}_{2}$ up to about $10^{-6}$ atm, but decreased quickly at higher oxygen partial pressures. The $\gamma_{\mathrm{CuO}_{0.5}}$ at lower oxygen partial pressures was about 4 . The $\gamma_{\mathrm{CuO}_{0.5}}$ from the correlation of Eerola et al., ${ }^{[14]}$ varies from 2.64 at a $\mathrm{pO}_{2}$ of $10^{-5}$ atm to 8.9 at a $\mathrm{pO}_{2}$ of $10^{-11}$ atm. In the present work, the raw data show that an average $\gamma_{\mathrm{CuO}_{0.5}}$ for the linear section $\left(\mathrm{pO}_{2}\right.$ from $10^{-10}$ to $10^{-7}$ atm) of Figure 2 is $3.52 \pm 0.25$ which is in broad agreement with the quoted results and within the uncertainty range given by Palacios and Gaskell. ${ }^{[12]}$

\section{B. Redox Equilibria of Copper and Iron}

Oxygen partial pressure could affect the $\mathrm{Fe}^{3+} / \mathrm{Fe}^{2+}$ ratio in calcium ferrite slags according to Reaction [3].

$$
(\mathrm{FeO})+0.25 \mathrm{O}_{2(g)}=\left(\mathrm{FeO}_{1.5}\right) \text {. }
$$

In copper-saturated calcium ferrite slags, copper can dissolve into the slag in the $\mathrm{Cu}^{+}$state according to Reaction [4]. Then, for ideal behavior, a plot of $\log (\mathrm{Cu})$ vs $\log \mathrm{pO}_{2}$ should be a straight line of slope 0.25 . However, if a portion of the $\mathrm{Cu}$ that dissolves in the slag is $\mathrm{Cu}^{2+}$, i.e., as $\mathrm{CuO}$ according to Reaction, [5] then this relationship will have a higher slope. 


$$
\mathrm{Cu}+0.25 \mathrm{O}_{2}=\mathrm{CuO}_{0.5}
$$

and

$$
\mathrm{Cu}+0.5 \mathrm{O}_{2}=\mathrm{CuO}
$$

The activity of $\mathrm{CuO}_{0.5}$ is given by Eq. [6]:

$$
a_{\mathrm{CuO}_{0.5}}=\gamma_{\mathrm{CuO}_{0.5}} X_{\mathrm{CuO}_{0.5}}=K_{1} a_{\mathrm{Cu}} \mathrm{pO}_{2}^{0.25} \text {, }
$$

and the activity of $\mathrm{CuO}$ is given by Eq. [7]:

$$
a_{\mathrm{CuO}}=\gamma_{\mathrm{CuO}} X_{\mathrm{CuO}}=K_{2} a_{\mathrm{Cu}} \mathrm{pO}_{2}^{0.5},
$$

where $K_{1}$ and $K_{2}$ are the equilibrium constants of Reactions [4] and [5], respectively.

If all the copper in the slag is considered as $\mathrm{Cu}^{+}$, then the apparent activity coefficient $\left(\gamma^{\prime}\right)$ is given by Eq. [8]:

$$
\gamma^{\prime}=\frac{a_{\mathrm{CuO}_{0.5}}}{X_{\mathrm{CuO}_{0.5}}+X_{\mathrm{CuO}}} .
$$

By rearranging Eqs. [6] and [7] and substituting into Eq. [8], an expression for the apparent activity coefficient (Eq. [9]) is found:

$$
\gamma^{\prime}=\frac{K_{1} a_{\mathrm{Cu}} \mathrm{p}_{\mathrm{O}_{2}}^{1 / 4}}{\frac{K_{1}}{\gamma_{\mathrm{CuO}_{0.5}}} a_{\mathrm{Cu}} \mathrm{p}_{\mathrm{O}_{2}}^{1 / 4}+\frac{K_{2}}{\gamma_{\mathrm{CuO}}} a_{\mathrm{Cu}} \mathrm{p}_{\mathrm{O}_{2}}^{1 / 2}} .
$$

By further rearranging, this equation can be simplified to Eq. [10]:

$$
\gamma^{\prime}=\frac{\gamma_{\mathrm{CuO}_{0.5}}}{1+\frac{\gamma_{\mathrm{CuO}_{0.5} K_{2}}}{\gamma_{\mathrm{CuO}} K_{1}} \mathrm{p}_{\mathrm{O}_{2}}^{1 / 4}} .
$$

The two activity coefficients $\gamma_{\mathrm{CuO}_{0.5}}$ and $\gamma_{\mathrm{CuO}}$ (assumed constant with varying $\mathrm{pO}_{2}$ ) can be calculated using Eq. [10] to fit the experimental data of $\gamma^{\prime}$ as a function of $\mathrm{pO}_{2}^{1 / 4}$.

Equation [10] is of the form

$$
y=\frac{a}{1+b x},
$$

where $y=\gamma^{\prime}$, and

$$
x=\mathrm{p}_{\mathrm{O}_{2}}^{1 / 4} .
$$

The parameters " $a$ " and " $b$ " represent $\gamma_{\mathrm{CuO}_{0.5}}$ and $\frac{\gamma_{\mathrm{CuO}_{0.5} K_{2}}}{\gamma_{\mathrm{C}} K_{1}}$, respectively. Using the optimized values of these parameters and the equilibrium constants $\mathrm{K}_{1}$ and $\mathrm{K}_{2}$, the activity coefficients $\gamma_{\mathrm{CuO}_{05}}$ and $\gamma_{\mathrm{CuO}}$ were calculated. With these activity coefficients as well as the activity of $\mathrm{CuO}_{0.5}$ and $\mathrm{CuO}$ obtained from Eqs. [6] and [7], and assuming the activity of copper is unity, the mole fractions of $\mathrm{CuO}_{0.5}$ and $\mathrm{CuO}\left(X_{\mathrm{CuO}_{0.5}}\right.$ and $\left.X_{\mathrm{CuO}}\right)$ in the slag were then calculated for different values of $\mathrm{pO}_{2}$.

For Reactions [4] and [5], the equations for the free energy of formation were obtained from linear correlations of free energy data contained in HSC Chemistry $5^{[32]}$ and are shown below.

$$
\begin{gathered}
\Delta \mathrm{G}_{4}^{\circ}=36.9 \mathrm{~T}-84,746(\mathrm{~J} / \mathrm{mol}) \\
\Delta \mathrm{G}_{5}^{\circ}=85.5 \mathrm{~T}-152,379(\mathrm{~J} / \mathrm{mol}) .
\end{gathered}
$$

Using the above procedure, the activity coefficients for $\mathrm{CuO}_{0.5}$ and $\mathrm{CuO}$ are 3.43 and 0.29 , respectively.

The sum of the mole fractions of these oxides was not the same as the initial mole fraction of copper oxide calculated from the analytical results. The recalculated concentrations were adjusted or normalized in constant proportions so the sum of calculated cuprous and cupric oxides was the same as in the original analysis (Table II). The correction to the $\mathrm{Fe}^{2+}$ content of slag was based on the amount of cuprous oxide in the slag, which was taken as the normalized content of $\mathrm{CuO}_{0.5}$ in the slag.

As a result of this normalization procedure, the assumption of constant $\gamma_{\mathrm{CuO}_{0.5}}$ and $\gamma_{\mathrm{CuO}}$ has been

\begin{tabular}{|c|c|c|c|c|c|}
\hline \multirow[b]{2}{*}{$\mathrm{pO}_{2}$} & \multicolumn{2}{|c|}{ Normalized Concentrations } & \multicolumn{2}{|c|}{$\begin{array}{l}\text { Recalculated Activity Coeffi- } \\
\text { cients }\end{array}$} & \multirow{2}{*}{$\begin{array}{l}\text { Ratio } \\
\frac{\gamma_{\mathrm{CuO}}}{\gamma_{\mathrm{CuO} O_{5}}}\end{array}$} \\
\hline & $X_{\mathrm{CuO}}$ & $X_{\mathrm{CuO}_{0.5}}$ & $\gamma_{\mathrm{CuO}}$ & $\gamma_{\mathrm{CuO}_{0.5}}$ & \\
\hline$\overline{10^{-11}}$ & 0.000054 & 0.00507 & 0.222 & 2.69 & 0.08 \\
\hline $10^{-10}$ & 0.000137 & 0.00724 & 0.285 & 3.35 & 0.09 \\
\hline $10^{-9}$ & 0.000413 & 0.01229 & 0.300 & 3.51 & 0.09 \\
\hline $10^{-8}$ & 0.001192 & 0.01995 & 0.328 & 3.85 & 0.09 \\
\hline $10^{-7}$ & 0.003455 & 0.03254 & 0.357 & 4.20 & 0.09 \\
\hline $10^{-6}$ & 0.012144 & 0.06431 & 0.322 & 3.78 & 0.09 \\
\hline $10^{-5}$ & 0.055038 & 0.16390 & 0.227 & 2.64 & 0.09 \\
\hline Avg & & & 0.292 & 3.43 & \\
\hline
\end{tabular}
relaxed. The variations of $\gamma_{\mathrm{CuO}_{0.5}}$ and $\gamma_{\mathrm{CuO}}$ with $\mathrm{pO}_{2}$ are shown in Table II. The average values of the activity coefficients are the same as in the initial values calculated. The ratio $\frac{\gamma_{\mathrm{CuO}}}{\gamma_{\mathrm{CuO}_{0.5}}}$ is close to constant over the range of $\mathrm{pO}_{2}$.

The variation of both $\gamma_{\mathrm{CuO}_{05}}$ and $\gamma_{\mathrm{CuO}}$ with $\mathrm{pO}_{2}$ does not follow a linear pattern. The actual coefficients are lower than average at high and low oxygen partial pressures and higher than average at intermediate

Table II. Normalized Concentrations of $\mathrm{CuO}$ and $\mathrm{CuO}_{0.5}$ and Corresponding Recalculated Activity Coefficients 


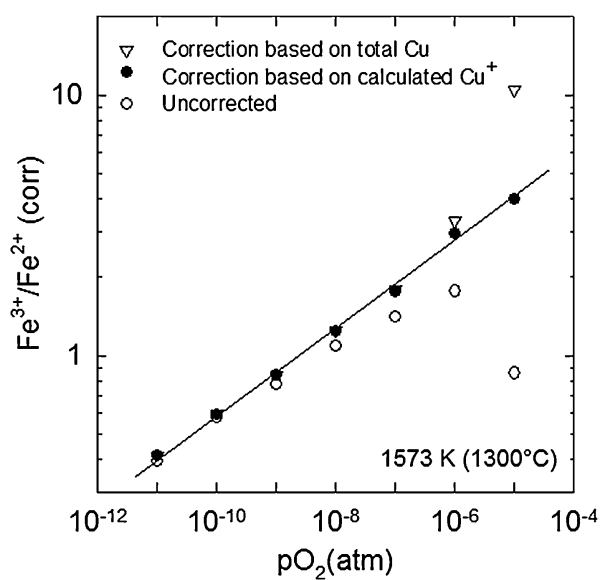

Fig. 5-The effect of correction procedures on the $\mathrm{Fe}^{3+} / \mathrm{Fe}^{2+}$ ratio in calcium ferrite slags in equilibrium with copper metal.

oxygen partial pressures. It may be possible to calculate the activity coefficients $\gamma_{\mathrm{CuO}_{0.5}}$ and $\gamma_{\mathrm{CuO}}$ and take into account their variation with oxygen partial pressure. However, in light of the results of corrected $\mathrm{Fe}^{3+} / \mathrm{Fe}^{2+}$ against $\log \mathrm{pO}_{2}$ shown in Figure 5, no adjustment to the calculation procedure was thought necessary in the present work.

The $\mathrm{Fe}^{3+} / \mathrm{Fe}^{2+}$ ratio of the slag has been corrected using the calculated value of $\mathrm{CuO}_{0.5}$ from Table II. The results are plotted in Figure 5 along with the corrected $\mathrm{Fe}^{3+} / \mathrm{Fe}^{2+}$ ratio if all the copper in the slag was assumed to be cuprous, as well as the uncorrected $\mathrm{Fe}^{3+} /$ $\mathrm{Fe}^{2+}$ ratio.

Figure 5 shows that if all the copper is assumed to be cuprous, then the corrected $\mathrm{Fe}^{3+} / \mathrm{Fe}^{2+}$ ratio is too high at high oxygen partial pressures $\left(10^{-6}\right.$ to $\left.10^{-5} \mathrm{~atm}\right)$. However, if cupric copper in the slag increases with oxygen partial pressure and if $\gamma_{\mathrm{CuO}_{05}}$ and $\gamma_{\mathrm{CuO}}$ are assumed to be constant over the oxygen partial pressure range, then the corrected $\mathrm{Fe}^{3+} / \mathrm{Fe}^{2+}$ ratio shows a good linear relationship with $\mathrm{pO}_{2}$ over the entire range of oxygen partial pressure. The slope of the line in Figure 5 is 0.17 which is in good agreement with the results of Takeda et al. ${ }^{[17]}$ of $0.17 \pm 0.01$ for copper-free calcium ferrite slag.

The simple dependence of the $\mathrm{Fe}^{3+} / \mathrm{Fe}^{2+}$ ratio on $\mathrm{pO}_{2}$ observed from Figure 5 is expected from the known behavior of transition metal redox couples in slags. Takeda et al. ${ }^{[17]}$ found that the $\mathrm{Fe}^{3+} / \mathrm{Fe}^{2+}$ ratio in copper-free calcium ferrite slag showed a simple dependence on the $\mathrm{pO}_{2}$ and lime content as shown in Eq. [13]. $\operatorname{Tran}^{[33]}$ also found a simple dependence of the ratio $\mathrm{Mn}^{3+} / \mathrm{Mn}^{2+}$ with $\mathrm{pO}_{2}$ over a wide range of oxygen partial pressures $\left(10^{-7}\right.$ to $\left.0.21 \mathrm{~atm}\right)$. Therefore, it is not unreasonable to also expect a simple dependence of the $\mathrm{Fe}^{3+} / \mathrm{Fe}^{2+}$ ratio on $\mathrm{pO}_{2}$ for copper-containing calcium ferrite slags.

Figure 6 shows a plot of corrected $\mathrm{Fe}^{3+} / \mathrm{Fe}^{2+}$ ratio against $\mathrm{pO}_{2}$, for the present work, and compared to data from Sun et al..$^{[21]}$ and the correlation formulated by Takeda et al. ${ }^{[17]}$ shown in Eq. [13]:

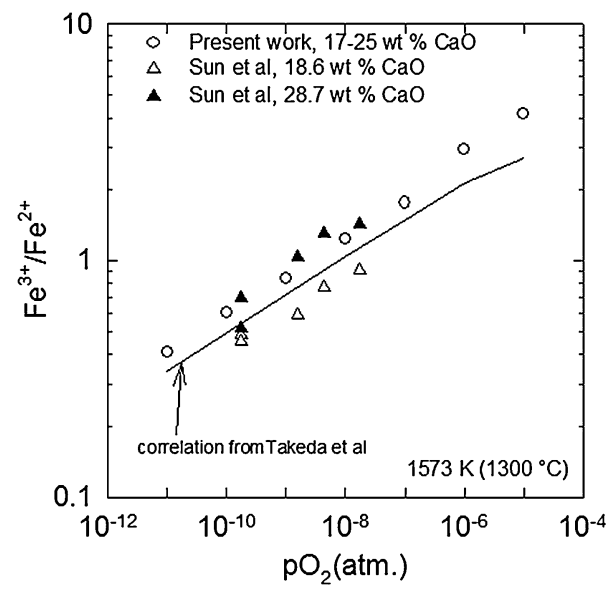

Fig. 6-The effect of oxygen partial pressure on the corrected $\mathrm{Fe}^{3+} /$ $\mathrm{Fe}^{2+}$ ratio of calcium ferrite slag and compared to results of Sun et al., ${ }^{[21]}$ and the correlation of Takeda et al. ${ }^{[7]}$

$$
\begin{aligned}
\log \frac{F e^{3+}}{F e^{2+}}= & 0.17 \log \left(\mathrm{pO}_{2}\right)+0.018(\text { wt pct } \mathrm{CaO}) \\
& +5500 / \mathrm{T}-2.52 .
\end{aligned}
$$

Takeda's ${ }^{[17]}$ correlation shows slightly lower $\mathrm{Fe}^{3+} /$ $\mathrm{Fe}^{2+}$ ratios compared to the present work. Their slags contained between 15 and 30 pct $\mathrm{CaO}$. The data of Sun et al. ${ }^{[21]}$ are at two $\mathrm{CaO}$ contents, 18.6 and 28.7 pct. The $\mathrm{CaO}$ content of slag used in the present work is between 17 and 24 pct, but most of the data points are between 22 and 24 pct. The corrected $\mathrm{Fe}^{3+} / \mathrm{Fe}^{2+}$ ratios from the present work falls between the two data sets of Sun et al. ${ }^{[21]}$ but is closer to the data at 28.7 pct $\mathrm{CaO}$.

The effect of copper on the $\mathrm{Fe}^{3+} / \mathrm{Fe}^{2+}$ ratio in calcium ferrite slag can be determined by comparing plots of $\log \mathrm{Fe}^{3+} / \mathrm{Fe}^{2+}$ against $\log \mathrm{pO}_{2}$ for slag containing copper (present work) and for slag which is copper free which can be obtained from the correlation of Takeda et al. ${ }^{[17]}$ (Eq. [13]). As shown in Figure 6, the $\mathrm{Fe}^{3+} / \mathrm{Fe}^{2+}$ ratio is slightly higher than predicted from Takeda's correlation. One possible explanation for this difference could be that copper in calcium ferrite acts as a "base" to increase the $\mathrm{Fe}^{3+} / \mathrm{Fe}^{2+}$ ratio.

This explanation does not agree with the conclusions of Yazawa and Takeda ${ }^{[11]}$ obtained for copper contents below 2 pct. They compared the dependence of the $\mathrm{Fe}^{3+} / \mathrm{Fe}^{2+}$ ratio on oxygen partial pressure for slags with and without copper and concluded that within the scatter of the experimental results, the effect of both $\mathrm{CuO}_{0.5}$ and $\mathrm{MgO}$ in slag on the $\mathrm{Fe}^{3+} / \mathrm{Fe}^{2+}$ ratio is relatively small, and the correlation developed for copper-free calcium ferrite slags could be used for copper-containing calcium ferrite slags.

Yazawa and Takeda ${ }^{[11]}$ may not have taken into account the effect of $\mathrm{CaO}$ dilution in slag due to increasing copper content at increasing oxygen partial pressures. According to Eq. [13], the $\mathrm{Fe}^{3+} / \mathrm{Fe}^{2+}$ ratio should decrease as the $\mathrm{CaO}$ level in the slag decreases. In this work, the $\mathrm{CaO}$ content of slag decreased from 23.5 


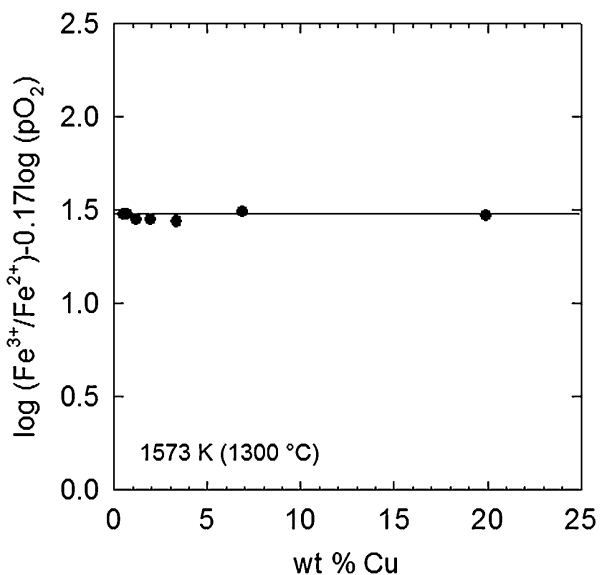

Fig. 7-Plot showing the independence of $\log \left(\mathrm{Fe}^{3+} / \mathrm{Fe}^{2+}-0.17\right.$ $\log \mathrm{pO}_{2}$ ) against wt pet $\mathrm{Cu}$ of slag.

to 17 pct as the $\mathrm{Cu}^{+}$content increased from 0.48 to 14.8 pet. However, the dilution of $\mathrm{CaO}$ by increasing copper dissolved in the slag cannot account for all the differences in the correlated data by Yazawa and Takeda ${ }^{[11]}$ and the present work. At low oxygen partial pressures, the copper content of slag is only 0.47 . The change in $\mathrm{Fe}^{3+} / \mathrm{Fe}^{2+}$ ratio due to $\mathrm{CaO}$ dilution in this case will be minimal.

The effect of dissolved copper on the $\mathrm{Fe}^{3+} / \mathrm{Fe}^{2+}$ ratio in slag can be determined by considering Eq. [13] which has been rearranged and shown as Eq. [14]:

$$
\log \frac{\mathrm{Fe}^{3+}}{\mathrm{Fe}^{2+}}=m \log \left(\mathrm{pO}_{2}\right)+\mathrm{C} .
$$

From Figure 5, the $\mathrm{Fe}^{3+} / \mathrm{Fe}^{2+}$ ratio is proportional to $\mathrm{pO}_{2}$ raised to the power of 0.17 . This power is equal to the slope ' $\mathrm{m}$ ' in Eq. [14]. The constant $C$ contains factors such as slag chemistry, temperature, and copper content of slag which might also affect the $\mathrm{Fe}^{3+} / \mathrm{Fe}^{2+}$ ratio. The dependence of the copper content in slag on the $\mathrm{Fe}^{3+} / \mathrm{Fe}^{2+}$ ratio can be determined by plotting log $\mathrm{Fe}^{3+} / \mathrm{Fe}^{2+}-0.17 \log \left(\mathrm{pO}_{2}\right)$ against the copper content of slag and is shown in Figure 7 . The horizontal line in Figure 7 indicates that the copper content over a broad range has no effect on the $\mathrm{Fe}^{3+} / \mathrm{Fe}^{2+}$ ratio in the slag for a given $\mathrm{CaO} / \mathrm{Fe}$ ratio, or copper oxide addition compensates for the dilution of $\mathrm{CaO}$ in the slag. More data are needed before an accurate account of the effect of copper in slags can be established.

\section{CONCLUSIONS}

At low partial pressures of oxygen, copper dissolves into calcium ferrite slag as the univalent species $\mathrm{CuO}_{0.5}$. Copper dissolution increases linearly with increasing oxygen partial pressure (in logarithm) with a slope of 0.23 . Beyond an oxygen partial pressure of about $10^{-7}$ atm, the copper solubility increases rapidly which can be attributed to the formation of divalent copper oxide $(\mathrm{CuO})$ in the slag.
The ferric/ferrous ratio $\left(\mathrm{Fe}^{3+} / \mathrm{Fe}^{2+}\right)$ in calcium ferrite slags has a linear dependence on oxygen partial pressure of 0.17 . The analytical determination of this ratio is affected by the cuprous $\left(\mathrm{Cu}^{+}\right)$copper content of the slag which acts to increase the apparent $\mathrm{Fe}^{2+}$ content and decrease the $\mathrm{Fe}^{3+}$ content of slag. The $\mathrm{Fe}^{3+} / \mathrm{Fe}^{2+}$ ratio was corrected by calculating the $\mathrm{Cu}^{+}$content of the slag by assuming that both $\gamma_{\mathrm{CuO} 0.5}$ and $\gamma_{\mathrm{CuO}}$ are independent of oxygen partial pressure. A logarithmic plot of corrected $\mathrm{Fe}^{3+} / \mathrm{Fe}^{2+}$ against $\mathrm{pO}_{2}$ shows a linear relationship over the entire range of oxygen partial pressure.

\section{ACKNOWLEDGMENTS}

The authors would like to thank Mr Harry Bryan who performed most of the chemical analyses. Financial support for this work was provided by the Australian Government Cooperative Research program through the former $\mathrm{G} \mathrm{K}$ Williams Cooperative Centre for Extractive Metallurgy, which was a joint venture between CSIRO Minerals and the University of Melbourne Department of Chemical Engineering.

\section{OPEN ACCESS}

This article is distributed under the terms of the Creative Commons Attribution License which permits any use, distribution, and reproduction in any medium, provided the original author(s) and the source are credited.

\section{REFERENCES}

1. T. Shibasaki, K. Kanamori, and M. Hayashi: Savard/Lee Int. Symp. Bath Smelt., J.K. Brimacombe, P.J. Mavkay, G.J.W. Kor, C. Birkert, and M.G. Ranada, eds., The Minerals, Metals and Materials Society, Warrendale, PA, 1992, pp. 147-58.

2. T. Shibasaki, M. Hayashi, and Y. Nishiyama: Extractive Metallurgy of Copper, Nickel, and Cobalt, vol. II: Copper and Nickel Smelter Operations, C.A. Landolt, ed., TMS, Warrendale, PA, 1993, pp. 1413-28.

3. M. Goto and K. Kanamori: Copper and Nickel Converters, R.E. Johnson, ed., 1979, pp. 210-24.

4. S. Ajima, M. Hayashi, Y. Nishiyama, and T. Shimizu: Fire Refining and Casting, J.D. McCain and J.M. Floyd, eds., TMS, 1993, pp. 333-49.

5. E. Jak, P.C. Hayes, C. Nexhip, and D.P. George-Kennedy: Proc. Copp. 2013, Santiago Chile, pp. 519-37.

6. C.J. Newman, D.N. Collins, A.J. Weddick, W.J. Chen, and P.J. Mackay: Proc. 4th Int. Conf. Copp. 99-Cobre 99, vol. 5, pp. 2945 .

7. A.J. Asteljoki, L.K. Bailey, D.B. George, and D.W. Rodolff: JOM, 1985, vol. 37, pp. 20-23.

8. S. Jahanshahi, M. Somerville, and R.G. Hollis: Proc. Copp. 95-Cobre 95 Int. Conf., vol. 4: Pyrometall. Copp., The Metallurgical Society of CIM, pp. 367-81.

9. S. Jahanshahi, S. Wright, and M. Somerville: Proc. 6th AusIMM Extr. Metall. Conf., Brisbane, pp. 89-94.

10. M. Somerville, T. Norgate, P. Jefferies, A. Vecchio-Sadus, and S. Jahanshahi: Proc. Copp. 99-Cobre 99 Int. Conf., TMS, vol. 6, pp. 15-26.

11. A. Yazawa and Y. Takeda: Trans. Jpn. Inst. Met., 1982, vol. 23, pp. 328-33.

12. J. Palacios and D.R. Gaskell: Metall. Trans. B, 1993, vol. 24B, pp. 265-69. 
13. A. Yazawa, Y. Takeda, and Y. Waseda: Can. Met. Q., 1981, vol. 20 (2), pp. 129-34.

14. H. Eerola, K. Jylha, and P. Taskinen: Trans Inst. Min. Metall., 1984, vol. 93, pp. C193-99.

15. Y. Takeda, S. Ishiwata, and A. Yazawa: Trans. Jpn. Inst Met., 1983, vol. 24, pp. 518-28.

16. E. Schurmann and G. Kraume: Arch. Eisenhuttenwes, 1976, vol. 47, pp. 435-39.

17. Y. Takeda, S. Nakazawa, and A. Yazawa: Can. Met. Q., 1980, vol. 19, pp. 297-305.

18. S. Nikolic, P.C. Hayes, and E. Jak: Metall. Mater. Trans. B, 2009, vol. 40B, pp. $892-99$.

19. S. Nikolic, P.C. Hayes, and E. Jak: Metall. Mater. Trans. B, 2009, vol. 40B, pp. 900-09.

20. S. Nikolic, P.C. Hayes, and E. Jak: Metall. Trans. B, 2009, vol. 40B, pp. 910-19.

21. S. Sun, Y. Sasaki, and G.R. Belton Metall. Trans. B, 1988, vol. 19B, pp. 959-65.

22. M. Timucin and A.E. Morris: Metall. Trans., 1970, vol. 1, pp. 3193-201.
23. H. Larson and J. Chipman: Trans. AIME-J. Met., 1954, pp. 759 62.

24. R.W. Gurry and L.S. Darken: J. Am. Chem. Soc., 1950, vol. 72, pp. 3906-10.

25. S. Yan, S. Sun, and S. Jahanshahi: Metall. Mater. Trans. B, 2005, vol. 36B, pp. 651-56.

26. M. Eguchi and A. Yazawa: Trans. Jpn. Inst. Met., 1977, vol. 18, p. 353.

27. S. Nikolic, P.C. Hayes, and E. Jak: Metall. Mater. Trans. B, 2008, vol. 39B, pp. 189-99.

28. T. Hidayat, E. Jak, D. Shishin, and S.A. Deeterov: Proc. Copp. 2013, Santiago Chile, pp. 507-518.

29. R. Altman and H.H. Kellogg: Trans. Inst. Min. Metall., 1972, vol. 81, pp. C163-75.

30. B.J. Elliott, J.B. See, and W.J. Rankin: Trans. Inst. Min. Metall., 1978, vol. 87, pp. C204-211.

31. Y. Takeda: Proc. Metall. Process. Early Twenty-First Century, Ed H.Y. Sohn, TMS 1994, pp. 453-66.

32. HSC Chemistry 5.11, Outokumpu Oy, Pori Finland.

33. T. Tran: PhD Thesis, The University of Melbourne, 1997. 